\title{
A „KURUC ROMANTIKA” MINT TURISZTIKAI VONZERŐ, AVAGY LEHET-E TURIZMUST ÉPÍTENI RÁKÓCZIRA ÉS A TENKES KAPITÁNYÁRA?
}

\author{
${ }^{1}$ Kiss Márton $-{ }^{2}$ Pap Norbert \\ ${ }^{1}$ PhD hallgató, PTE Földtudományok Doktori Iskola; kiss.marton1990@gmail.com \\ 2 egyetemi tanár, PTE TTK Földrajzi és Földtudományi Intézet, Politikai Földrajzi, Fejlödési \\ és Regionális Tanulmányok Tanszék; pnorbert@gamma.ttk.pte.hu
}

DOI: 10.15170/TVT.2022.07.01.02.

\begin{abstract}
Absztrakt
II. Rákóczi Ferenc (1676-1735) és a „kuruc kor” emlékezete fontos részét képezi a magyar identitásnak. Élete és korszaka igazán turbulens időszaka volt az ország történelmének. A 20. században Rákóczi emlékezete politikai rendszereken túlmutató jelleggel is bírt, így annak épülése szinte töretlen volt. A 21. században azonban kérdésként merül fel, hogy ez a kuruc romantika milyen módon érhető tetten a turizmusban, valamint bír-e még vonzerővel. Kutatásunk egységes szempontok segítségével kívánja bemutatni, hogy a kuruc korszakhoz kötődő desztinációk hogyan teljesítenek a 21. század elején.
\end{abstract}

Kulcsszavak: emlékezeti hely, kuruc romantika, II. Rákóczi Ferenc, örökségturizmus

\section{THE "KURUC" ROMANTICS AS A TOURISM ATTRACTION - IS IT POSSIBLE TO BUILD TOURISM ON PRINCE RÁKÓCZI AND THE CAPTAIN OF THE TENKES HILL?}

\begin{abstract}
The memory of Ferenc II. Rákóczi (1676-1735) and the "Kuruc Age" is an important part of Hungarian identity. His life and era was a truly turbulent period in the Hungarian history. Rákóczi's memory in the 20th century survived several political regimes, so its popularity was almost unbroken. In the 21st century, however, the question arises as to how this „kuruc romance" can be achieved in action in tourism, and whether it still has appeal. Our research aims to show how heritage tourism in the Kuruc era is performing at the beginning of the $21 \mathrm{st}$ century with the help of clear aspects.
\end{abstract}

Keywords: place of remembrance, kuruc romanticism, II. Ferenc Rákóczi, heritage tourism 


\section{Bevezetés}

A kuruc küzdelmek hagyománya és II. Rákóczi Ferenc emlékezete fontos részét képezi a magyar nemzeti identitásnak. A magyar nemzeti panteonban Thököly Imre (1657-1705) és II. Rákóczi Ferenc (1676-1735) - beleértve olyan fiktív szereplöket is, mint például A Tenkes kapitányából megismert Buga Jakab és Eke Máté - a kedvelt és népszerü hősök közé tartoznak. Szerepüket az oktatásban is megtalálhatjuk, így a magyar társadalom jelentős része találkozott már a nevükkel és a hozzájuk kapcsolódó emlékezeti helyekkel.

Kérdést jelent ugyanakkor, hogy ez az általánosnak mondható társadalmi ismertség megalapozhat-e turisztikai aktivitást, valamint a történelmi szereplök emlékezeti helyei (és emlékpontjaik) milyen turisztikai vonzerőt képezhetnek. A kutatásunk gyakorlati jelentőségén túl (megalapozhat helyi turisztikai fejlesztéseket) reményeink szerint elméleti következtetések levonására is módot adhat: a turisztikai kínálat révén mérhetővé válik a kuruc hagyomány földrajzi elterjedtsége, ismertsége, részben pedig annak népszerüsége is.

\section{Szakirodalmi áttekintés és a kutatás módszerei}

A kulturális turizmus napjainkban jelentős növekedésen, fejlődésen megy keresztül. Napjaink turisztikai keresletében egyre inkább felértékelödnek az egyedi sajátosságokkal, kulturális arculattal rendelkező desztinációk. A globalizáció hatása, hogy a turizmusban megnőtt az uniformitás, ugyanakkor a kereslet egyre inkább diverzifikálódik, föként a fiatal értelmiségiek keresik ezeket (KÁNTOR 2021). A kulturális értékek, az örökségelemek egyre jelentősebb szerepet töltenek be a helyi fejlesztésekben, hiszen csak így nyerhetnek egyedi, jól megkülönböztethetö arculatot az egyes turisztikai térségek, illetve helyek. A kuruc romantika értékei egy ilyen lehetőséget kínálnak a Kárpát-medence magyarlakta térségein belül. A jelen vizsgálat nem teljesen elözmény nélküli, hiszen a hungarikumok sorában megjelennek olyan kulturális elemek (TÖZSÉR 2021), amelyek gyökerei a kuruc korra nyúlnak vissza (pl. tárogató hangszer, karikás ostor, a klasszikus magyar szablyavívás hagyományai stb.). A kulturális turizmus kutatása során a kuruc hagyomány legfontosabb térségeinek, mint a Dél-Dunántúlnak (GÁSZNÉ BÖSZ 2020), annak is különösen a református magyar térségeinek (ÁCS et al. 2017) és a Felső-Tisza vidékének (DEÁK et al. 2019) attrakciói részben már feltárásra kerültek. A fejlesztési törekvések több jó gyakorlatra is támaszkodhatnak (HORVÁTH 2020, GÁSZNÉ BÖSZ - PENTZ 2020).

Az ún. kuruc időszakot Thököly Imre és II. Rákóczi Ferenc Habsburg-ellenes küzdelmeinek idejére helyezi a történeti kutatás. A történelmi események sora 1673-tól (a „bujdosók” első támadásától) a majtényi fegyverletételig (1711) tartanak. Továbbá a hagyományok egészét közelebbröl vizsgálva a néprajztudomány arra jutott, hogy a 19. században - pontosabban Thaly Kálmán fellépésétől kezdve (1872) - volt egy fellángolása a kuruc emlékezettel kapcsolatos sokoldalú érdeklődésnek (Magyar Néprajzi Lexikon).

A kuruc hagyomány gyüjtőnév alá legtöbbször epikus-lírai alkotásokat szoktak sorolni (különböző dalok, nóták, versek), de ide tartoznak a mondák is. Nem csak Thökölyröl és Rákóczi Ferencről maradtak fenn ilyen történetek, hanem például Vak Bottyánról, Bezerédy Imréről, Ocskai Lászlóról és Károlyi Sándorról is. A már említett Thaly Kálmán munkássága újabb színt vitt ebbe a hagyományba, szinte romantikussá téve azt a kortársak és később az utókor számára egyaránt. A Rákóczi személyéhez kapcsolódó emlékezeti diskurzusok a 20. században az ő 1906-os kassai újratemetésével kezdődtek, ugyanakkor később is fontos részét képezték az állami emlékezetpolitikának (KISS 2021b). Rákóczi személye a két világháború közötti időszakban is általában a költő és hadvezér Zrínyi Miklós utódaként és Széchenyi István munkásságának előkészítőjeként jelent meg (KISS 2015). 
A trianoni békeszerződéssel a határon túlra szakadt magyarság számára Rákóczi személye az identitás megőrzésének egyik kulcsa volt, aki egyben egy tragikus sorsú hőst is megjelenített. Az anyaországiak számára Rákóczi személye a haza szeretetét, valamint a szenvedések méltósággal való viselését szimbolizálta.

A 20. század második felében Rákóczi emlékezete új tartalommal bővült. Az állami emlékezet számára személye beilleszkedett az „elnyomó-elnyomott” ellentétpárba, így időszakával is többet foglalkoztak. Az „elnyomás elleni küzdelem és a szabadság kivívása” gondolat határozta meg a Rákóczi (és egyben a kuruc) romantikát az országban. Több kiadvány jelent meg ebben az időszakban a kuruc költészet, valamint a fejedelem életének bemutatására (KÖPECZI VÁRKONYI 1976, VARGA 1977, KÖPECZI 1982).

A rendszerváltás után Rákóczi emlékezete egy időre halványodni kezdett. A hagyományosnak mondható nagy évfordulók $(2003,2011)$ a politikai turbulenciák - például az országgyülési választások - miatt rendre csak szerényebb ünnepségekre adtak lehetőséget. 2015-ben ebben változás történt, amikor a Magyar Országgyülés egy emléknapot fogadott el Rákóczi emléke előtt tisztelegve (március 27-ét). 2018-ban pedig a magyar országgyülés elfogadta, hogy a következő évet (2019) Rákóczi-emlékévvé nyilvánítsa (KISS 2021b). Ez a folyamat élesen felvetette a kérdést: hogyan áll a kuruc hagyományápolás helyzete Magyarországon és a határon túli területeken?

\section{Az 1976-os Rákóczi-emléktúra mint a mai kuruc tematikájú turisztikai aktivitások előzménye}

Kutatásaink első körében megvizsgáljuk, hogy a kádári Magyarországon miképpen jelent meg a fóként Rákóczi személyéhez kapcsolódó kuruc romantika mint a turisztikai aktivitás alapja. Ehhez módszerként forráselemzést alkalmaztunk. Fö forrásunk egy dokumentum, mely a fejedelem születésének 300. évfordulójával kapcsolatban készült el Rákóczi-emléktúra címmel. Ebből tudjuk azonosítani a fontosabb érintett településeket, amelyekhez leírást is mellékeltek. A helyneveket már rögzítettük egy táblázatban, a magyarokat és külföldieket egyaránt (1. táblázat). Ezek mellett a szerzők csatoltak egy jegyzéket az érintett megyei múzeumokról is, amelyeket látogatásra méltónak találtak.

Az adatok földrajzi szempontból két részre bonthatók:

1. Magyarországi települések: Budapest és további 65 település jelent meg benne. Az egy megyére eső legkevesebb emlékpont két esetben (Baranya, Fejér) jelenik meg, míg a legmagasabb emlékpontszámmal (nyolc) Szabolcs-Szatmár-Bereg megyét azonosíthatjuk.

2. Magyarországon kívüli helyek (35 helyszín): az akkori állami körből azóta megszünt a Szovjetunió, Csehszlovákia és Jugoszlávia, de az utódállamok a helyeket megörökölték. Az akkori Csehszlovákiában 25 emlékezeti hely volt, amelyek manapság Szlovákia területén fekszenek (KERTÉSZ 1976).

A Hazafias Népfront Országos Tanácsa fokozott figyelemmel követte a különböző kulturális mozgalmak munkáját. Ez nem pusztán szervezői, hanem koordináló feladatokat is jelentett egyben. A különböző művelődési szektorokat kézben tartó szervezet foglalkozott a különböző túramozgalmak helyzetével. A Hazafias Népfront Országos Elnöksége Honismereti Bizottságának alapszervezetei között megtalálhatók voltak az „országjáró, természet- és műemlékvédelmi munkacsoportok", amelyek feladata az ilyen típusú rendezvények lebonyolítása volt. II. Rákóczi Ferenc születésének 300. évfordulójára külön túramozgalmat kezdeményeztek, ami illeszkedett a korábban már létező és működő hasonló szerveződések közé. Ilyenre volt példa a tanácsköztársasági, a Dózsa-, a Petőfi- és a felszabadulási emléktúra mint eseménysorozat (HAZAFIAS NÉPFRONT 1976). 
A túramozgalomban résztvevők számára a szervezőbizottság - az OKISZ-KIOSZ Testnevelési és Sportosztálya, a Spartacus Turista Egyesülete és a Magyar Természetbarát Szövetség - egy külön füzetet adtak ki Rákóczi emléktúrák 1976 címmel, hogy azokba gyüjteni lehessen a megadott települések pecsétjeit. Magyarországon ez 66 megyei helyszínt és a fővárost jelentette. A helyszínekhez kisebb terjedelmü magyarázó szövegek is tartoztak. A külhoni helyeken hasonló módon jelezték a látogatásra alkalmas pontokat, így Ausztriában 2, Csehszlovákiában (a mai Szlovákiában) 26, Franciaországban 2, Jugoszláviában (ma Szerbia) 1, Lengyelországban 5, a Német Szövetségi Köztársaságban 1, Romániában 7, a Szovjetunióban (ma Ukrajnában) 5, Törökországban pedig 4 emlékezeti helyet soroltak fel. A külföldi célok látogatására a szervezők külön autóbuszjáratokat indítottak a Coopturist Utazási Iroda segítségével, amely utak lenyomatait több esetben is megtalálhatjuk az országos lapok hasábjain (TURISTA JELENTI).

A kiadvány bevezetőjében Juhász Róbert (a Rákóczi Emlékbizottság titkára) kifejtette, hogy Rákóczi születésének 300. évfordulója alkalmas lehet arra, hogy keretében a hazafiságot, a függetlenséget és a társadalmi haladást egyaránt ünnepelhessük. Külön kiemelte, hogy a Hazafias Népfront - immáron állandó jelleggel - támogatta a mozgalmat, hogy önmagunk és a „szocialista hazánk javát szolgálhassa”. Jutalmazták is azokat, akik részt vettek a túrákon: alumínium, aranyozott vagy kerámia plakettet adtak a megfelelő számú helyet felkeresők számára (KERTÉSZ 1976).

Természetesen a helyi érdekü (megyei) lapokban több beszámoló is megjelent a túrával kapcsolatban. A Turista Magazin évfordulós számából megtudjuk, hogy a helyi szervezetek közül a Borsod megyei Természetbarát Szövetség külön rendezvényt tartott a fejedelemre való méltó megemlékezés jegyében. A leírásból megtudhatjuk, hogy az öt túrából álló sorozat célja az olyan földrajzi és kulturális helyek felkeresése, amelyek a fejedelemre és az általa vezetett szabadságharcra vonatkoznak (például Felsővadász, Regéc, Sárospatak, Szerencs és Vaja). Hasonló leírást olvashatunk a Honismeret folyóirat hasábjain a jászkiséri Honismereti Szakkör vezetőjének tollából, amelynek tagjai a szomszédos Csehszlovákia Rákóczi-emlékhelyeit látogatták meg (HAGYMÁSY 1976).

A kiadvány külön térképen (mellékletben) rögzíti a túramozgalomban résztvevő emlékezeti pontokat. Az ábrából jól látható, hogy igyekeztek minden megyében ilyen pontokat kiválasztani, miközben nagymértékben támaszkodtak a helyi hagyományokra. A mellékelt térképen jól látható a szervezők törekvése, hogy a történelmi megalapozottság mellett az egyenlö eloszlás elve is - amennyire lehet - érvényesüljön, bár a történelmi események egyenlőtlen eloszlása miatt inkább az aszimmetria jellemző. Minden megyébe igyekeztek legalább 2-3 turisztikai célpontot kijelölni, ugyanakkor az ország északkeleti részén lévő megyékben összesen húsz helyszínt találhatunk. Kivételt képez ez alól Zala megye, ahol csak egyetlen helyet (Nagykanizsa) jelöltek meg látogatási helynek. Hozzá kell tenni, hogy jelenleg Egervár is Zala megyéhez tartozik, így az ábra szerint két emlékezeti hellyel bír. A hadi események ugyanakkor valójában Vas megyéhez kötik az emlékezést. 
1. ábra. Az 1976-os Rákóczi túramozgalom desztinációi

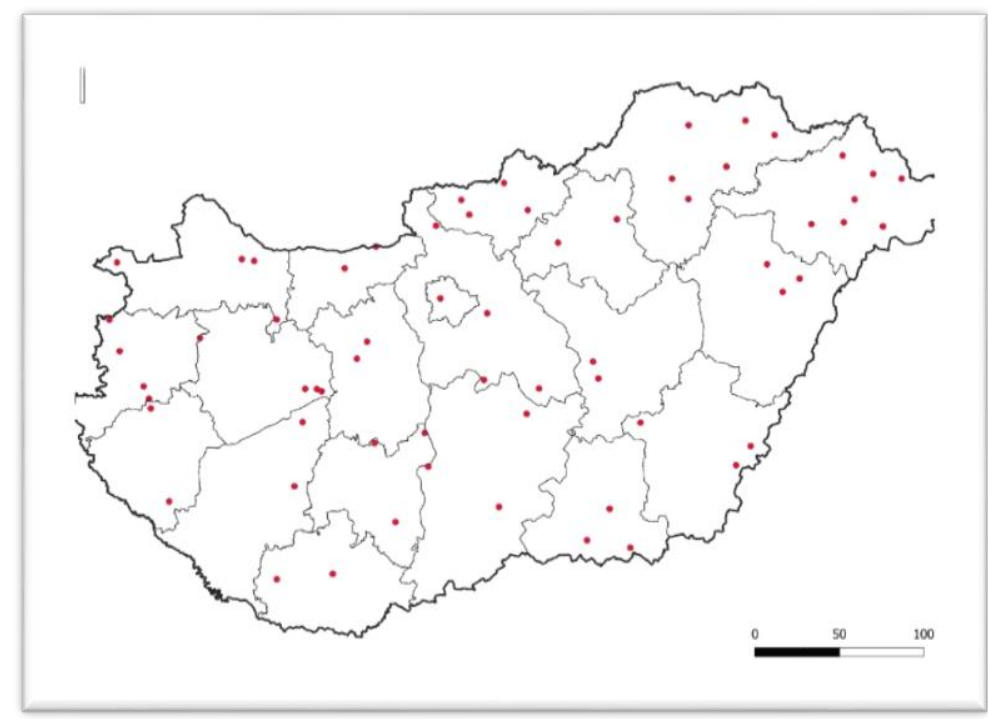

Forrás: KERTÉSZ (1976) alapján saját szerkesztés

Összességében elmondható, hogy az 1976-ban indított Rákóczi-túramozgalom jól illeszkedett a Magyarországon létező természetjáró programok közé. A fejedelem születésének 300 . évfordulója az országos emlékezetpolitikában is kiemelkedő esemény volt, amit jól erősített ez a programlehetőség. A mozgalom hatása, hogy II. Rákóczi Ferenc emléke a mai napig fellelhető az országban, és nem csak az épített környezetben, hanem a természetjáró társadalmi közeg miatt a minket körbevevő természetben is. Ugyanakkor arra is rámutat, hogy milyen nagymértékben politikai kérdés a Rákóczival és társaival való foglalkozás.

A mai kuruc romantika típusú turizmus alapjait ebben a korszakban rakták le, az idősebb korosztály révén pedig él még a társadalmi bázisa is. Ezt a korszakot, a helyeket és az aktivitást tekinthetjük a mai turisztikai fejlesztések kiindulási alapjának.

\section{A kárpát-medencei kuruc romantika elemei}

A kuruc romantika építőkockái személyekböl és eseményekből állnak össze. Thököly Imre (1657-1705), a bujdosók fővezére 1682-ben feleségül vette Zrínyi Ilonát és ezzel Rákóczi Ferenc mostohaapja lett. Ebben az évben lett felső-magyarországi fejedelem és három évig töltötte be ezt a pozíciót. Életét törökországi emigrációban fejezte be.

Zrínyi Ilona (1663-1703) II. Rákóczi Ferenc édesanyja és I. Rákóczi Ferenc felesége volt, férje halála után pedig Thököly Imréhez ment hozzá. 1685 és 1688 között a munkácsi vár védője volt, majd követte férjét törökországi emigrációjába.

II. Rákóczi Ferenc (1676-1735) erdélyi fejedelem, a róla elnevezett Rákóczi-szabadságharc (1703-1711) vezetője. A háború végén emigrációban keresett támogatókat küzdelmeihez, végül Törökországban telepedett le.

Bercsényi Miklós (1665-1725) kuruc fögenerális, II. Rákóczi Ferenc közeli barátja, egyben a szabadságharc egyik vezetője volt. Követte Rákóczit az emigrációba és itt is halt meg.

Esze Tamás (1666-1708) kuruc brigadéros, a tiszaháti felkelés vezetője. A fejedelem 1708-ban nemességet adományozott neki, számos közterület őrzi a nevét.

Bottyán János (1643 k.-1709) kuruc generális, a Rákóczi-szabadságharc egyik legendás hadvezére. Legismertebb tettei a Dunántúlhoz kötődnek, különösen az 1705-ös hadjárat idején (HECKENAST 2005). 
A kuruc romantika következő építököveit jelentik azok a helyek, ahol a szabadságharc nagy eseményei zajlottak. Ilyennek tekinthetjük az első országos gyülést 1705-ben Szécsénynél (itt kötött szövetséget a Rákóczit támogatók tábora), az 1707-es ónodi gyülést (ahol kimondták a Habsburg-ház trónfosztását), valamint az 1708-as sárospataki gyülést (a jobbágyszabadság kimondásának helyszínét). Kisebb gyülések is voltak a korszakban, így például 1708-ban Sümegen a dunántúli rendek esetében, azonban a háború közelsége miatt ennek emlékezete szinte azonnal megfakult (KÖPECZI - VÁRKONYI 1976).

A szabadságharc hadtörténeti részeit áttekintve elmondható, hogy a nagyobb csaták esetében a kurucok szinte kivétel nélkül vereséget szenvedtek: Koroncónál (1704), Nagyszombatnál (1704) Zsibónál (1705), Trencsénnél (1708) és Romhánynál (1710). Kisebb győzelmeik voltak, mint például Szomolánynál (1704), Győrvárnál (1706) és Kölesdnél (1708) (KÖPECZI VÁRKONYI 1976).

Az alábbi táblázatban olvashatjuk a kuruc romantika tipikus eseteit a vonzerő jelentősége, erőssége alapján. Az adatokból helyi, regionális, országos és nemzetközi kategóriákat tudtunk megállapítani, hogy azokat össze tudjuk hasonlítani.

1. táblázat: A kuruc tematikájú desztinációk erősség szerinti csoportjai

\begin{tabular}{|c|c|c|c|}
\hline szint & megnevezés & település & indoklás \\
\hline 1 & helyi & 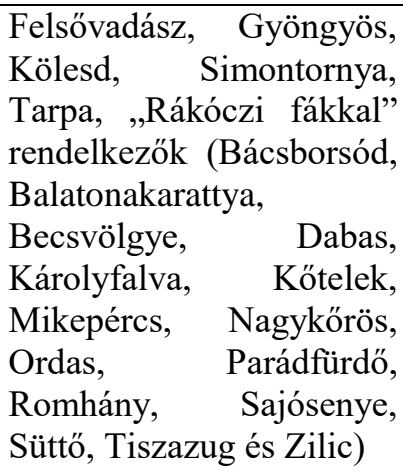 & $\begin{array}{l}\text { A Rákóczi-szabadságharc tipikus helyszínei, } \\
\text { nevezetes személyeihez köthető települések. Vak } \\
\text { Bottyán, Esze Tamás és maga Rákóczi személyét } \\
\text { megidéző helyek. Itt állítottak emléket az összes } \\
\text { Rákóczi-fával bíró településnek. (Index-cikk } \\
\text { alapján). Miskolc pedig egy Rákóczi-túra kiinduló } \\
\text { helyszíne. }\end{array}$ \\
\hline 2 & regionális & Siklós & $\begin{array}{l}\text { A Tenkes kapitánya címü filmsorozatnak és } \\
\text { könyvnek köszönhetően országosan is ismert, de } \\
\text { regionális szinten fontos emlékezeti hely. A } \\
\text { történelmi tapasztalatok helyett inkább az utólagos } \\
\text { emlékezetépítés terméke, de kurucos helyként } \\
\text { müködik. Ugyanakkor zajlottak hiteles történelmi } \\
\text { események is a környéken. }\end{array}$ \\
\hline 3 & országos & Sárospatak & $\begin{array}{l}\text { A Rákóczi-családhoz köthető, ugyanakkor inkább a } \\
\text { két Györgyhöz, valamint a családhoz. A kuruckor } \\
\text { csak kis részben jelenik meg. }\end{array}$ \\
\hline 4 & $\begin{array}{l}\text { több } \\
\text { országban } \\
\text { érdekelt }\end{array}$ & Borsi, Kassa, Munkács & $\begin{array}{l}\text { Az egyik Rákóczi szülőhelye, a másik } \\
\text { újratemetésének (sírjának) helye. A harmadik volt } \\
\text { családjának híres vára, ahol édesanyja emléke is } \\
\text { élénk lehetett. }\end{array}$ \\
\hline 5 & $\begin{array}{l}\text { „külföldi” } \\
\text { célok }\end{array}$ & $\begin{array}{l}\text { Tekirdag, } \text { Izmit }^{1} \text {, Grobois- } \\
\text { Yerres }\end{array}$ & A külföldi Rákóczi-emlékezet föbb helyei. \\
\hline
\end{tabular}

Forrás: Saját szerkesztés

\footnotetext{
1 Thököly Imre és Zrínyi Ilona tartózkodási helye volt törökországi emigrációjukkor. 2008-ban nyílt meg a Thököly Emlékház, amely méltó emléket állít kettejüknek. Isztambultól 130 kilométerre található.
} 
Meg kell említenünk a Budapesten található Rákóczi-szobrot is, amely a Kossuth téren - a Parlament szomszédságában - helyezkedik el. Ez nem fér bele a kategóriarendszerbe, ugyanakkor a külföldi vendégek, valamint a magyarok is itt találkoznak legtöbbet Rákóczival.

2. ábra: A vizsgálatba bevont települések térbeli elhelyezkedése

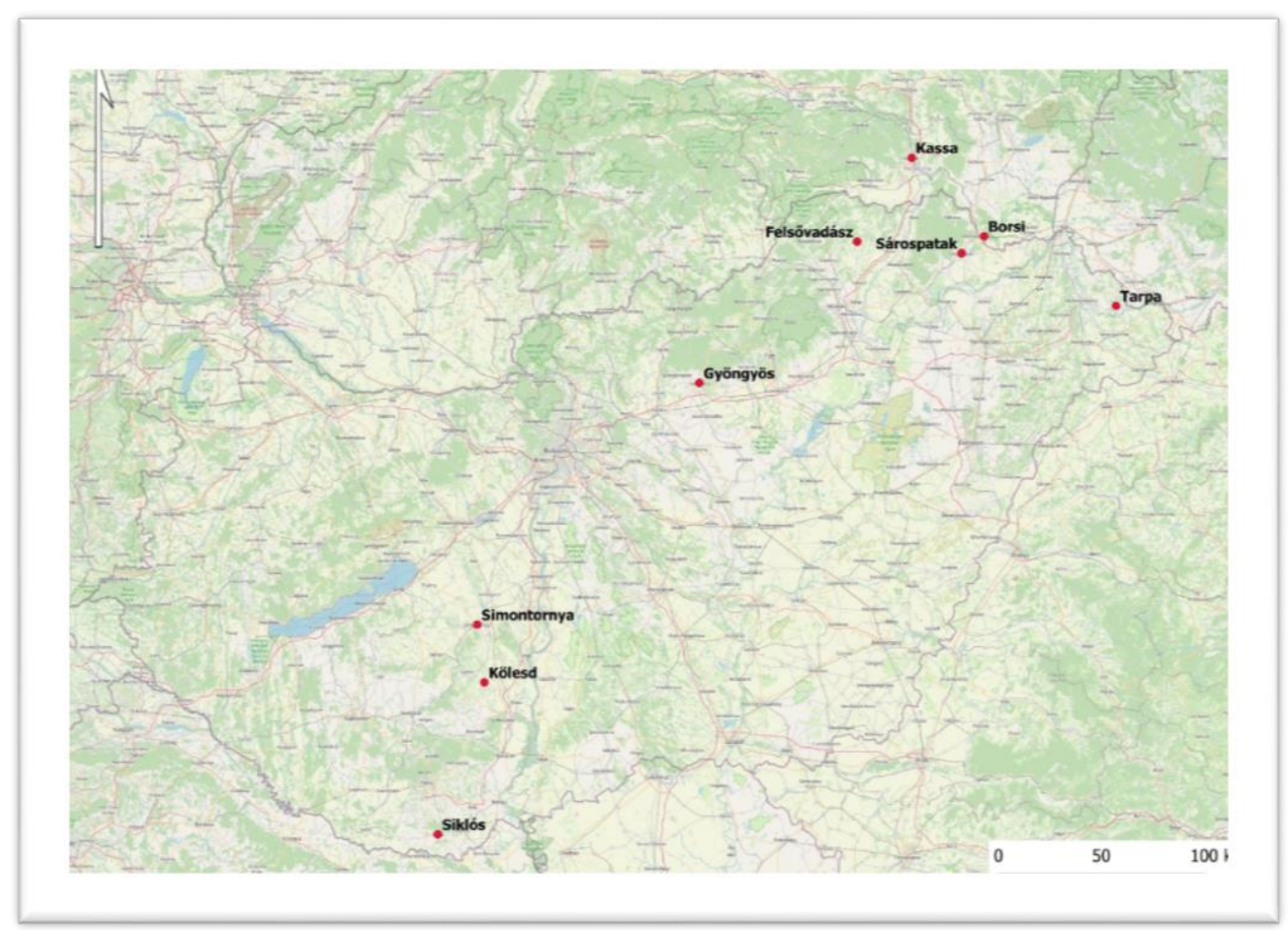

Forrás: Saját szerkesztés

\section{A kuruc kulturális hátterü kínálat elemzése}

Az alábbiakban egy reprezentatív mintán áttekintjük, hogy ma milyen kuruc hátterü kulturális turisztikai kínálat létezik Magyarországon. Az elemzésben az alábbi öt kategóriát vettük figyelembe:

1. Az attrakció típusa: emlékmü, természeti elem, épített örökség, múzeum, csatahely;

2. Van-e belőle képzett termék és megvásárolható-e?

3. Megközelíthetőség;

4. Van-e weboldala, van-e közösségi média (social media) felülete (Facebook, Instagram, Youtube)?

5. Van-e kapcsolódó, kuruc hagyományokon alapuló imázstermék: kuruc kitűző, Bottyán-krémes, labancpecsenye stb.

Az elemzés során a vizsgálat mintájába a következő helyeket soroltuk be:

Helyi szintü emlékhelyek

I. Felsővadász ${ }^{2}$ (Borsod-Abaúj-Zemplén megye):

1. A településen található kastély II. Rákóczi Ferenc egyik kedvelt tartózkodási helye volt. A Rákóczi-család egyik korábbi tagja, Rákóczi Zsigmond 1517-ben szerezte meg

\footnotetext{
${ }^{2}$ https://felsovadasz.hu/Telepulesrol/ (utolsó hozzáférés: 2022. január 4.).
} 
Felsővadászt és családi ágának megkülönböztetésére felvette a „felsővadászi” előnevet. Ilyen értelemben Felsővadászi II. Rákóczi Ferenc így a kötődése elsődlegesnek mondható. A Rákóczi-kastély jelenleg az általános iskola egyik épületeként funkcionál (NAGY 1862).

2. Jelenleg nincsen erre alapozott turisztikai termék.

3. Budapesttől több mint 200 kilométerre, Miskolctól 40 kilométerre található település. Közösségi közlekedéssel Miskolcról közelíthető meg.

4. A település saját weboldallal rendelkezik, amely közli az alapvető tényeket a helyi nevezetességekröl.

5. Jelenleg nem található imázstermék a településen.

II. Gyöngyös (Heves megye)

1. A Rákóczi-szabadságharc egyik hőséhez, Bottyán Jánoshoz (Vak Bottyánhoz) köthető emlékezeti hely. 1709-ben a helyi ferences templomban temették el. 1906 óta emléktábla jelzi e helyet, 1969-ben pedig lovasszobrot állítottak Bottyán emlékére.

2. Az emlékezeti terek legnagyobb része szabadtéren található meg, így kereskedelmi jellegük nincs.

3. Budapesttől 80 kilométerre található, közösségi közlekedéssel (busz, vonat) átszállással közelíthető meg.

4. A helyi Mátra Múzeum nem tartalmaz Bottyán Jánosra vonatkozó kiállítást, inkább a természeti értékek állnak a középpontban. A történelmi személyiségről elnevezett helyi iskolának van külön weboldala és Facebook-oldala egyaránt.

5. A terület nem bír a kuruc hagyományokra támaszkodó termékekkel.

III. Kölesd ${ }^{3}$ (Tolna megye)

1. A település környékén (a Harc-hegyen) zajlott le 1708-ban Béri Balogh Ádám vezetésével a Rákóczi-szabadságharc egyik utolsó kuruc győzelme. 2002-ben közadakozásból mellszobrot avattak a csatát vezető Béri Balogh Ádám kuruc brigadérosnak.

2. Jelenleg nincs a kuruc attrakcióhoz kapcsolódó termék.

3. Budapestről 150 kilométerre, Szekszárdtól 25 kilométerre található a 6-os főút közelében. Közösségi közlekedéssel, busszal érhető el.

4. A települési weboldalon közölnek információkat a település turisztikai látványosságairól. Innen tudhatunk Béri Balogh Ádám életéről, valamint a település környékén zajlott kuruc harcokról.

5. Jelenleg nem található az eseményhez kötődő turisztikai termék vagy szolgáltatás.

IV. Simontornya ${ }^{4}$ (Tolna megye)

1. A szabadságharc idején komoly szerepet játszott az itteni várkastély. Bottyán János 1705-ben vette be, később számos katonai esemény színhelye volt. Múzeum müködik a várkastélyban, mely a 18 . századi nemesi életet mutatja be.

\footnotetext{
${ }^{3}$ http://www.kolesd.hu/ (utolsó hozzáférés: 2022. január 4.).

${ }^{4}$ https://simontornyaivar.hu/ (utolsó hozzáférés: 2022. január 4.).
} 
2. A településen nincsen kifejezetten kuruc tematikával foglalkozó termék vagy szolgáltatás.

3. Autóval a 61-es és a 63-as föutak közelében található, Siófoktól és Dunaújvárostól közel 50 kilométerre. Vonattal a Budapest-Pécs fövonalon helyezkedik el, személyvonattal közelíthető meg.

4. A múzeum a Tolna megyei Wosinszky Mór Megyei Múzeum részeként működik. Integrált weboldallal rendelkezik, Facebook-oldal csak részlegesen működik. Ennek fókuszában a középkori vár, Mátyás király kora. a végvári harcok és a nemesi élet bemutatása állnak.

5. Az emlékezeti hely nem rendelkezik külön, a kurucokra vagy Rákóczira vonatkozó turisztikai tárggyal vagy szolgáltatással.

V. $\operatorname{Tarpa}^{5}$ (Szabolcs-Szatmár-Bereg megye):

1. Esze Tamás Emlékpark, Esze Tamás és II. Rákóczi Ferenc lovasszobra, valamint a Kuruc Történelmi Dombormüfal tekinthető emlékezeti terméknek.

2. Jelenleg nem épül rá kereskedelmi/turisztikai tevékenység.

3. Budapesttől 320 kilométerre, Nyíregyházától 80 kilométerre található, közel a magyarukrán határhoz. Távolsági közlekedéssel körülményesen érhető csak el.

4. A település a weboldalán mutatja be a Rákóczi-szabadságharc és Esze Tamás életét és a kurucokhoz köthető alkotásokat. Ezek közül kiemelkedik az Esze Tamás emlékpark, ahol a névadó szobra mellett II. Rákóczi Ferenc lovasszobra is megtalálható (ezt 2003ban állították). Bíró Lajos szobrász később újabb történelmi emlékkel egészítette ki a kuruc emlékezetet - 2021-ben került helyére a Kuruc Történelmi Dombormüfal utolsó darabja. Más digitális csatorna egyelöre nem található. A településhez köthető „Esze Tamás Népe Tarpa" címủ Facebook-oldal a közéleti események mellett többször oszt meg tartalmakat Esze Tamás emlékezetéről is.

5. Jelenleg nem található imázstermék a településen.

\section{Regionális}

VI. Siklós ${ }^{6}$ (Magyarország)

1. A 13. században épített vár komoly erösségnek számított a maga korában. A Rákócziszabadságharc idején a kuruc csapatok többször is támadták és blokád alá vették. A vár azonban egy regény és filmsorozat, az Örsi Ferenc által jegyzett A Tenkes kapitánya révén vált a kuruc emlékezés regionális központjává.

2. A településen kurucokhoz köthető szolgáltatás vagy termék nem található. 2010-ben volt egy próbálkozás „kuruc-kori ételek főzőversenyére” a helyi Tenkes Csárdában.

3. Budapestről 240 kilométerre, Pécstől 30 kilométerre fekszik. Vonattal nem közelíthető meg. Közel fekszik a magyar-horvát határhoz.

4. Weboldal és Facebook-oldal is segíti a látogatókat a tájékozódásban. Ezek átböngészése ugyanakkor nem segíti a kuruc korszak iránt érdeklődőket, ugyanis arról szinte semmi információ nem található rajtuk.

\footnotetext{
${ }^{5}$ http://www.tarpa.eu/ (utolsó hozzáférés: 2022. január 5.).

${ }^{6}$ https://www.siklosivar.hu/hu (utolsó hozzáférés: 2022. január 5.).
} 
5. Az emlékezeti hely nem rendelkezik külön a kuruc korszakra vagy Rákóczi Ferencre vonatkozó imázstermékkel vagy kapcsolódó szolgáltatással.

Országos hely

VII. Sárospatak ${ }^{7}$ (Magyarország)

1. A sárospataki Rákóczi-múzeum jelenti az emlékezeti helyet a kuruc romantika kapcsán. Harcok sem a végvári időszakban, sem a szabadságharc idején itt nem zajlottak, inkább birtokigazgatási központként funkcionált. Rákóczi gyakran tartózkodott itt, családi öröksége volt.

2. A környéken nem lelhető fel külön a kuruc időszakra vonatkozó termék vagy szolgáltatás. Az emlékhely inkább a Rákóczi-családnak állít emléket és nem külön II. Rákóczi Ferencnek.

3. Budapestről 250 kilométerre található, vonattal is megközelíthető a fővárosból. A magyar-szlovák határhoz való közelségének köszönhetően több emlékhellyel együtt is látogatható.

4. Weboldallal rendelkezik a múzeum, ahol több kiállítás is foglalkozik a Rákócziszabadságharc eseményeivel és II. Rákóczi Ferenc emigrációjával. Ugyanakkor ez csak a kínálat kis részét képezi, nem tekinthető egyértelmủen „szabadságharcos” emlékezeti helynek.

5. A hely nem rendelkezik a Rákóczi-szabadságharchoz köthető imázstermékkel vagy szolgáltatással.

Több országot érintö emlékhelyek

8. Borsi ${ }^{8}$ (Borša, Szlovákia)

1. A Rákóczi-család kastélya, egyben II. Rákóczi Ferenc születési helye. Az épületben múzeum müködik, valamint szállodaként és közösségi térként is funkcionál.

2. Az épületben müködő háromcsillagos szállodában II. Rákóczi Ferenc brigadérosairól elnevezett szobák, valamint a Rákóczi-család három nőtagjáról (Zrínyi Ilona, Báthori Zsófia, Lorántffy Zsuzsanna) elnevezett szoba található. Különböző kiállítások is szerveződtek a fejedelem életének bemutatására.

3. Magyar viszonylatban (Budapestről) nagyjából 260 kilométerre van, Sátoraljaújhely érintésével közelíthetö meg. Utóbbi irányba vonattal is el lehet jutni, ahonnan taxival vagy gyalog (5 kilométer) is meg lehet közelíteni.

4. Weboldal és Facebook-oldal is segíti a látogatókat. A Covid-vírushelyzet miatt utóbbi népszerüsége megnőtt, mivel itt közvetlenül el tudták érni a potenciális vendégeket. A kommunikációban fontos szerepet kap II. Rákóczi Ferenc mellszobra, amely szinte mindig megjelenik a vizuális tartalmakban.

5. Ilyen terméknek minősülhet a már bemutatott élményközpontú szolgáltatás (étterem, szálloda), valamint szabadulószoba és virtuális-valóság kiállítás. Az étteremben nem található a korszakra vonatkozó étel vagy ital.

9. Kassa ${ }^{9}$ (Košice, Szlovákia)

\footnotetext{
${ }^{7}$ https://www.rakoczimuzeum.hu/hu/ (utolsó hozzáférés: 2022. január 4.).

${ }^{8}$ https://www.borsikastely.eu/ (utolsó hozzáférés: 2022. január 4.).

${ }^{9}$ https://slovakia.travel/hu (utolsó hozzáférés: 2022. január 4.).
} 
1. Kassa városa több tekintetben is kötődik II. Rákóczi Ferenchez és az általa vezetett szabadságharchoz. 1706-ban katonai események színhelye volt, többször időzött itt a fejedelem a harcok során. 1906-ban Rákóczi és bujdosótársai - köztük Bercsényi Miklós, Csáky Krisztina, Esterházy Antal, Sibrik Miklós, Zrínyi Ilona és Thököly Imre - földi maradványait itt helyezték végső nyugalomra a Szent Erzsébet székesegyházban. 1920 után ez a terület Magyarországon kívülre került és komoly vitákat okozott a csehszlovák állam és a magyar kisebbségek között. 1938 és 1945 között ismételten Magyarországhoz tartozott, majd véglegesen elkerült tőle (KISS 2021a). E tiszavirágéletü magyar uralom idején jelent meg egy külön „Rákóczi-ház” felállításának ötlete, amely csak 1990 után valósulhatott meg. Az átalakítási tervek a második világháború idejére estek, amely a pénzhiány miatt nem következhetett be. A háború lezárultával és a párizsi békeszerződéssel (1947) - a terület ismét Csehszlovákiához került. A ház felépítésének ügye nem is került elő egészen a rendszerváltásig. Különlegességét jelenti, hogy ez egy, a Rákóczi által tervezett rodostói kuruc ház hasonmásaként jött létre, a bútorok mellett több eredeti használati tárgyat is találhatunk. Az udvaron pedig 2006ban felállították Rákóczi bronzszobrát.

2. Kassa turisztikai jelentőségét számos tanulmányban követhetjük végig. Ezen a hagyományon belül II. Rákóczi Ferenc emlékezete egy korábban vitákkal teli identitásnak adott teret, mégpedig a felvidéki magyarság öntudatával kapcsolódott össze. A függetlenedő Szlovákiában néhol fellobbanó viták után jelenleg ez a kérdés nem jelent olyan súlyos politikai vitát, mint korábban.

3. Magyarországról Miskolcon keresztül érhető el autóval és közösségi közlekedéssel (busz, vonat) egyaránt. Budapesttől 260 kilométerre, Miskolctól közel 90 kilométerre található a szomszédos Szlovákiában.

4. A városban több emlékezeti hely is kötődik II. Rákóczi Ferenchez, így ezeket egységes oldalon megtalálni körülményes. A legjobb összefoglalót a TravelGuide-on találhatjuk, amely foglalkozik a Szent Erzsébet székesegyházzal és a Rodostói házzal egyaránt. Hasonlóan segítheti a megértést a Slovakia Travel című weboldal, ahol információkat kaphatunk az emlékezeti helyek lokalizációjáról, a belépőjegyek áráról és a közeli szálláshelyekről. A Rodostói ház jelenleg a „Kelet-szlovákiai Múzeumhoz” tartozik, weboldaluk azonban csak szlovák nyelven érhető el (magyar, angol vagy egyéb nyelv választása még opcióként sem szerepel itt).

5. Rákóczi személyéhez a már említett helyeken lehet találni kisebb-nagyobb emléktárgyakat. Ezek főként a róla szóló könyveket, valamint a Kassához kötődő emléktárgyakat jelentik.

\section{„, Külföldi célok”}

X. Rodostó ${ }^{10}$ (Tekirdag, Törökország)

1. II. Rákóczi Ferenc és bujdosó társainak utolsó állomáshelye, itt is halt meg a fejedelem 1735-ben. Később a magyar emigráció jelképévé vált, amely összeforrt Rákóczi nevével. A hamvak hazaszállítása után is fontos emlékezeti hely maradt, részben Mikes Kelemen emlékének őrzőjeként. A Török-Magyar Kultúra Háza a mai napig várja az idelátogatókat. A településen található épületek mellett külön utca és park fogadja a látogatókat, ahol Rákóczi Ferenchez és társaihoz köthető szobrokat találhatunk.

\footnotetext{
${ }^{10}$ https://rodosto.hu/hu/rodosto.html (utolsó hozzáférés: 2022. január 4.).
} 
2. Az emlékezeti hely nyitott részein nem szükséges díjat fizetni. A kiállításra - mely a fejedelem és a köré szerveződő „magyar kolónia” életével foglalkozik - jelenleg három török líra (75 forint) a belépő.

3. Isztambultól (Törökország) 120 kilométerre nyugatra található település.

4. A rodostói kiállítás külön weboldallal rendelkezik, különböző nyelveken (magyar, angol, török). A kiállításokról, látogatásokról is külön bejegyzések szólnak, koordináták segítik az idejutást. Érdekesség, hogy a vezetők szövegét elöre is letölthetjük, hogy abból tájékozódhassunk.

5. Külön Rákóczihoz köthető imázsterméket nem találhatunk itt.

XI. Grobois ${ }^{11}$ (Yerres, Franciaország):

1. A két világháború közötti magyar kolónia állított egy emlékoszlopot II. Rákóczi Ferenc emlékére. A hely jelenleg is afféle történelmi zarándokhelynek számít a Franciaországban élő magyarok számára. Ugyanitt található egy II. Rákóczi Ferenc szobor is, erősítve az emlékezést.

2. Jelenleg nincsen az emlékmühöz kapcsolódó kereskedelmi vagy szervezett turisztikai tevékenység.

3. Budapesttől több mint 1200 kilométerre, Párizstól körülbelül 20 kilométerre délkeletre található, az RN6-os fóúthoz közel.

4. Az emlékmü nem rendelkezik külön weboldallal. Rövid bejegyzéseket találhatunk különböző webfelületeken.

5. Jelenleg nincs külön imázstermék a területen.

\section{Következtetések}

A kiválasztott emlékhelyek elemzése arra mutat, hogy a kuruc romantikában rejlik még fejlesztési potenciál. Ugyanakkor a megvizsgált turisztikai aktivitások mértéke egyelőre nem igazán éri el azt a szintet, hogy jelentős tényezővé válhasson. A vizsgált helyszínek közül csak néhol találhatunk tipikusan kurucokra vagy II. Rákóczi Ferencre utaló elemeket. Látható, hogy a helyi hagyományok szerepét nem szabad alábecsülni, különösen a „kisebb” hősök esetében (Gyöngyösön Bottyán János, Tarpán Esze Tamás) erős identitásformáló erővel bírnak. Ugyanakkor Rákóczi személye az egyetlen, aki bír akkora elismertséggel, hogy az egész magyar szállásterületen hivatkozási alapként bírjon, azonban még a hozzá köthető kastélyok müködtetői sem használták ki ezt lehetőséget.

A vizsgálatba bevont települések segíthetnek abban, hogy ilyen irányú fejlesztések esetén mire lehetne támaszkodni. Az 1976-os kiadványhoz hasonlóan elmondható, hogy az ország északkeleti része - és a vele határos szlovák területek - bírnak azzal a kulturális többlettel, erős üzenetekkel, hogy Rákóczi és kurucainak emlékezetét fenntarthassák és érdemi kulturális turizmus épüljön rá.

A kisebb, helyi érdekủ emlékezeti helyek esetében egy dunántúli turisztikai „klaszter” bírhat fejlesztési potenciállal: így például egy kuruc túra megszervezésével, amely kapcsán szinte az összes emlékezeti helyet egybe lehetne szervezni. Siklós esete a példa arra, hogy egy korábban erős alapokon álló, irodalmi és filmmüvészeti alkotásokkal megtámogatott kultuszt a 21. században nem tartanak fenn, pedig üde színt jelenthetne a kínálatukban. Ugyancsak jellemző, hogy a kulináris élvezeteket keresők egyelőre nem találhatnak olyan terméket, melyek a kuruc

11 https://www.kulhonimagyarok.hu/programok/julianus-program/europa/franciaorszag/ii-rakoczi-ferencemlekmu-yerres/ (utolsó hozzáférés: 2022. január 4.). 
korszakba repíthetné őket. Rákóczi nevéhez több élvezeti cikk is - így például különböző korszakban sörök és a „Rákóczi Fejedelmi Pálinka Udvarház” termékei (pálinka, bor, pezsgő, tábláscsokoládé, drazsé, praliné) - is kötődik. ${ }^{12}$ Ezek az imázstermékek azonban nem társulnak közvetlenül egy emlékezeti térhez, pedig fejlesztésük kívánatos lenne. Meg lehetne ismét próbálni a két „kuruc klaszter” összekötését is, ahogyan azt a „Tarpa-Tenkes-lovastúra” szervezői is gondolták az 1970-es évek elején. Ez az országban lévő „kurucos” helyeket is összeköthetné, és sportolási lehetőségnek sem lenne utolsó. ${ }^{13}$

Egyetlen pozitív kivételként a borsi kastélyban történő fejlesztések említhetők, amelyek valódi kárpát-medencei érzést kölcsönöznek a kuruc kultusznak. Ez a helyszín, igazodva a 21. századi igényekhez, nem pusztán emlékezeti helyként és kiállítótérként müködik, hanem szabadulószobával és virtuálisvalóság szobával is bír.

A földrajzi és történeti adottságok alapján felmerülhet a különböző - Rákóczihoz köthetö emlékek összeszervezése túrákká. A Rákóczi-emlékezet klaszterét ilyen esetben két nagyobb tömbre választhatjuk, úgy mint az északkeleti magyar országrész és Szlovákia keleti részét magába ölelő régióra (Sárospatak, Borsi, Kassa), valamint a Dunántúl közepén található, Bottyán János és Béri Balogh Ádám emlékezetét követő területre (Simontornya, Kölesd, Siklós). Az első egyes elemeiben müködik, a feladat a kikerekítése, mélyítése.

Az utóbbi - a dunántúli túra - kialakítása még várat magára. Ugyan a kuruc történelem iránt érdeklődés nem tünt el a térségből, de itt még elemeiben is csak alig felfedezhető egy kuruc tematikájú regionális turisztikai termék.

A vírusjárvány okozta bezárkózás felértékelte az egyéni és családi rendezvényeket, így újult erővel jelenhetnek meg a különböző tematikus túrák. Ilyen például a Borsod-Abaúj-Zemplén Megyei Természetjáró Szövetség által szervezett, a Zempléni-hegységben kijelölt „Rákóczitúra”, amely szabadon látogatható, a végén pedig jelvénnyel gazdagodhat a résztvevő. Kísérletet lehetne tenni egy ilyen vagy ehhez hasonló túrára a Dunántúlon is. Jelenleg is müködő szolgáltatásként ki kell emelnünk a Magyar Turisztikai Ügynökség által fenntartott „Hol vagy Kajla” programot. Ennek keretében az alsó tagozatban járó (1-4. osztályos) diákok részesülhetnek utazási kedvezményben és látogatási támogatással (pecséttel). Ez követi a korábbi turista hagyományokat, így különböző programokat szerveznek a gyermekek és a szülők számára egyaránt. Így jelentek meg például a „Várak és kastélyok”, a „Budapesti kalandok” vagy a „Kajla körök” fantázianévvel ellátott eseménysorozatok. A meglévő infrastruktúra felhasználásával lehetőség lenne egy különálló programsorozat létrehozására, mely akár a „Kuruc túra” nevet is viselheti. Ennek alapját II. Rákóczi Ferenc születésének 350. évfordulója adná és illeszkedhetne egyéb programokhoz. ${ }^{14}$

\section{Összefoglalás}

A kuruc romantika elméletileg jelentős erőforrása lehetne a kulturális turisztikai fejlesztéseknek. Egy olyan zavaros korszakot jelenít meg, amelyben bővelkedhetünk szélsőséges (ezáltal érzelmekkel teli) élményekben, illetve ezekhez köthető szereplőkben és emlékhelyeikben. II. Rákóczi Ferenc történelmi szerepe és közelgő évfordulója ráirányítja a figyelmet arra, hogy ezt a kincset nem szabad veszni hagyni. A „kuruc romantika” emlékei ugyanis nem csak Magyarországon belül, hanem a közeli országokban (Szlovákia, Ukrajna, Románia) is potenciállal bírhatnak. A magyar turisztikai hagyományban a Rákóczihoz és kurucaihoz kapcsolódó emlékezeti helyek kiépítését már korábban megkezdték, azonban ez a hagyomány nagyon megfakulni látszik a 21. században. Az új évezred fejlesztései között ki kell

\footnotetext{
12 www.rakoczi-delikat.hu (utolsó hozzáférés: 2022. január 4.).

${ }^{13} \mathrm{https}$ ://adt.arcanum.com/hu/view/Nepszabadsag_1971_06/?pg=8\&layout=s

${ }^{14}$ Információk: https://mtu.gov.hu/cikkek/hol-vagy-kajla-14 (utolsó hozzáférés: 2022. január 5).
} 
emelnünk a borsi kastélyhoz köthetőket, melyek utat mutathatnak más, Rákóczihoz köthető létesítmények számára is.

\section{Irodalomjegyzék}

ÁCS, M. - KRÁNICZ, G.- SZALAI, G. - VARGA, SZ. (2017): Reformátusok Baranyában. Scriptura Kiadó, 184.

DEÁK, A. - LIPTÁKNÉ - JUHÁSZ, A. - B. PRISTYÁK, E. (2019): Felső-Tisza-vidéki örökségtúrák tapasztalata, a müemlék-bemutatás új formái alapján. Turisztikai és Vidékfejlesztési Tanulmányok, 4(2) pp. 39-58.

GÁSZNÉ BŐSZ, B. (2020): Dél-Dunántúl, a kulturális turisztikai régió? Turisztikai és Vidékfejlesztési Tanulmányok 5(3) pp. 74-90.

GÁSZNÉ BŐSZ, B. - PENTZ, M. (2020): Friss élmények történelmi környezetben: "élő várak" a németországi várak útján. Turisztikai és Vidékfejlesztési Tanulmányok 5(4) pp. 72-90.

HAGYMÁSY, S. (1976): Honismereti Rákóczi-emléktúra. Honismeret, 1976(6): pp. 10-11.

HECKENAST, G. (2005): Ki kicsoda a Rákóczi-szabadságharcban? História, MTA Történettudományi Intézet, Budapest.

HORVÁTH, A. (2020): Örökségvédelem és múzeumi attrakciófejlesztés a miklósvári Kálnokykastélyban. Turisztikai és Vidékfejlesztési Tanulmányok 5(4) pp. 5-28.

KÁNTOR, SZ. (2021): A kulturális programkínálat megítélése a kultúrafogyasztás tükrében: vizsgálatok Debrecen, Györ, és Veszprém egyetemistái körében. Turisztikai és Vidékfejlesztési Tanulmányok 6(3) pp. 76-91.

KERTÉSZ, M. (1976): Rákóczi emléktúrák. Budapest.

KISS, M. (2021b): A Rákóczi-kultusz alakulásának száz éve (1920-2019). Századvég. 1(2): pp. $149-174$.

KISS, M. (2021a): II. Rákóczi Ferenc alakjának identitásképző ereje Kassa példáján. KöztesEurópa: Társadalomtudományi Folyóirat. 12(2) pp. 75-88.

KISS, M. (2015): A Rákóczi-szabadságharc értelmezési keretei (elméleti megfontolások), In: Tuboly-Vincze, G. (szerk.): XIV. Országos Grastyán Interdiszciplináris Konferencia előadásai. PTE Grastyán Endre Szakkollégium, Pécs. pp. 106-114.

KÖPECZI, B. - VÁRKONYI, Á. (1976): II. Rákóczi Ferenc. Gondolat Kiadó, Budapest.

KÖPECZI, B. (1982): Döntés előtt. Az ifjú Rákóczi eszmei útja. Akadémiai Kiadó, Budapest.

NAGY, I. (1862): Magyarország családai. Czimerekkel és nemzedékrendi táblákkal. Ráth Mór, Pest.

TŐZSÉR, A. (2021): A hungarikumok szerepe a települések fejlődésében. Turisztikai és Vidékfejlesztési Tanulmányok 6 : 4 pp. 51-66.

VARGA, I. (1977): A kuruc küzdelmek költészete. Akadémiai Kiadó, Budapest.

A Turista jelenti. Turista Magazin, 1975(11): pp. 27-28.

A Hazafias Népfront Országos Elnöksége Honismereti Bizottságának beszámolója a honismereti mozgalom helyzetéről és feladatairól. Honismeret, 1976 (2-3): pp. 3-16 


\section{Egyéb források}

Borsi kastély. https://www.borsikastely.eu/ (utolsó hozzáférés: 2022. január 4.)

Felsővadász: https://felsovadasz.hu/Telepulesrol/ (utolsó hozzáférés: 2022. január 4.)

Kölesd: http://www.kolesd.hu/ (utolsó hozzáférés: 2022. január 4.)

Kuruc énekek, kuruc dalok, kuruc nóták. Magyar Néprajzi Lexikon. 3. kötet. http://mek.niif.hu/02100/02115/html/3-1053.html (utolsó hozzáférés: 2022. 01. 03)

Nyilas Gergely: Jön, jön: Rákóczi-emlékfák településeinek országos találkozója. https://index.hu/mindekozben/poszt/2016/10/12/jon_jon_rakocziemlekfak_telepuleseinek_orszagos_talalozoja/ (letöltve: 2022.01.03.)

Rákóczi Múzeum (Sárospatak): https://www.rakoczimuzeum.hu/hu/ (utolsó hozzáférés: 2022. január 4.)

Siklós: https://www.siklosivar.hu/hu (utolsó hozzáférés: 2022. január 5.)

Simontornya: https://simontornyaivar.hu/ (utolsó hozzáférés: 2022. január 4.)

Tarpa: http://www.tarpa.eu/ (utolsó hozzáférés: 2022. január 5.)

Travel Slovakia. https://slovakia.travel/hu (utolsó hozzáférés: 2022. január 4.) 